\title{
Social Insects Dominate Eastern US Temperate Hardwood Forest Macroinvertebrate Communities in Warmer Regions
}

\author{
Joshua R. King ${ }^{1 *}$, Robert J. Warren ${ }^{2}$, Mark A. Bradford ${ }^{3}$ \\ 1 Biology Department, University of Central Florida, Orlando, Florida, United States of America, 2 Biology Department, SUNY Buffalo State, Buffalo, New York, United States \\ of America, 3 Yale School of Forestry and Environmental Studies, Yale University, New Haven, Connecticut, United States of America
}

\begin{abstract}
Earthworms, termites, and ants are common macroinvertebrates in terrestrial environments, although for most ecosystems data on their abundance and biomass is sparse. Quantifying their areal abundance is a critical first step in understanding their functional importance. We intensively sampled dead wood, litter, and soil in eastern US temperate hardwood forests at four sites, which span much of the latitudinal range of this ecosystem, to estimate the abundance and biomass $\mathrm{m}^{-2}$ of individuals in macroinvertebrate communities. Macroinvertebrates, other than ants and termites, differed only slightly among sites in total abundance and biomass and they were similar in ordinal composition. Termites and ants were the most abundant macroinvertebrates in dead wood, and ants were the most abundant in litter and soil. Ant abundance and biomass $\mathrm{m}^{-2}$ in the southernmost site (Florida) were among the highest values recorded for ants in any ecosystem. Ant and termite biomass and abundance varied greatly across the range, from $<1 \%$ of the total macroinvertebrate abundance (in the northern sites) to $>95 \%$ in the southern sites. Our data reveal a pronounced shift to eusocial insect dominance with decreasing latitude in a temperate ecosystem. The extraordinarily high social insect relative abundance outside of the tropics lends support to existing data suggesting that ants, along with termites, are globally the most abundant soil macroinvertebrates, and surpass the majority of other terrestrial animal (vertebrate and invertebrate) groups in biomass $\mathrm{m}^{-2}$. Our results provide a foundation for improving our understanding of the functional role of social insects in regulating ecosystem processes in temperate forest.
\end{abstract}

Citation: King JR, Warren RJ, Bradford MA (2013) Social Insects Dominate Eastern US Temperate Hardwood Forest Macroinvertebrate Communities in Warmer Regions. PLoS ONE 8(10): e75843. doi:10.1371/journal.pone.0075843

Editor: Judith Korb, University of Freiburg, Germany

Received June 25, 2013; Accepted August 21, 2013; Published October 8, 2013

Copyright: (c) 2013 King et al. This is an open-access article distributed under the terms of the Creative Commons Attribution License, which permits unrestricted use, distribution, and reproduction in any medium, provided the original author and source are credited.

Funding: JRK was supported by National Science Foundation (NSF) grant DEB 1020415 and an In-House grant from the University of Central Florida. MAB and RJW were supported by NSF grants DEB-0823293 and DEB-0218001 to the Coweeta LTER Program (http://www.nsf.gov). The funders had no role in study design, data collection and analysis, decision to publish, or preparation of the manuscript.

Competing Interests: The authors have declared that no competing interests exist.

*E-mail: joshua.king@ucf.edu

\section{Introduction}

To a degree seldom grasped even by entomologists, the modern insect fauna has become predominantly social. - Bert Hölldobler and Edward O. Wilson, The Ants.

The conspicuous presence of social insects in almost all terrestrial ecosystems has captivated the imaginations of biologists, motivating more than a century's worth of ecological study of ants and termites [1], [2], [3]. Social insects appear most abundant and most diverse - in the tropics, subtropics, and warm temperate latitudes [1], [2], [4]. Their ecological importance, however, is defined by their influence on nutrient cycling, decomposition, soil engineering, predation upon arthropods, and plant community turnover [5], [6], [7], [8], [9], [10]. Ants and termites are thus described as ecosystem engineers because, along with earthworms, they are typically the only physically large members of the soil invertebrate fauna that are presumed to have sufficient abundance and biomass to influence the formation and maintenance of soil structure and to regulate biological processes across landscapes [6], [7], [9], [11]. Understanding the magnitude of their influence on these ecosystem processes, however, is limited by a lack of data regarding areal abundance (individuals $\mathrm{m}^{-2}$ ) and biomass (grams dry mass $\mathrm{m}^{-2}$ ) estimates [9], [12].

Whereas the engineering effects of earthworms are studied across many systems because their areal abundance is quantified, work on termites as engineers has focused mainly on a few sites in the humid tropics and some African savannas with estimates of areal abundance [2], [9], [13], [14]. Ant engineering effects are, in comparison, little studied as almost nothing is known about their areal abundance [1], [3], [5], [8], [9], [10], [13], [15], [16]. This paucity of data is cited as the reason for omitting ants and termites from syntheses of biogeographical patterns in belowground communities [17], but see also [18]. The shortage of social insect observations probably occurs because most soil fauna studies do not estimate social insect biomass: this requires searching for and collecting whole colonies [19], [20], [21].

The primary focus of our study is to provide areal abundance and biomass estimates of soil macroinvertebrates. That is, invertebrates $>2 \mathrm{~mm}$ in body width and all ants and termites. This primarily excludes mites and Collembola. We emphasize improving estimates of social insect abundance and biomass across a latitudinal gradient in eastern US temperate hardwood forest [22] to stimulate further investigations into their role in ecosystem 
processes, paralleling work for salamanders in temperate forest [23]. These forests have a broad geographical range and are important to humans for recreation, carbon storage, timber production and wildlife conservation [24].

Ants and termites are generally warm-loving and numerically dominant in the tropics (and thus described as thermophilic; [1], [9], [13]). So we hypothesized that the range of temperate forests that our sampling covered would show that social insects would increase in areal abundance from northern to southern latitudes, but we expected them to be subdominant to other taxa in these communities, and especially so in northern, cooler regions [2], [25], [26], [27].

\section{Materials and Methods}

\section{Study Sites}

The study was conducted in mid-late August (Connecticut, North Carolina and Georgia sites) and early September (Florida site) of 2011 in four locations spanning $\sim 12^{\circ}$ latitude along the eastern US in second-growth hardwood forests. In Connecticut, the northernmost site, sampling was conducted at Yale Myers Forest in Windham and Tolland Counties $\left(41^{\circ} 57^{\prime} \mathrm{N} 72^{\circ} 07^{\prime} \mathrm{W}\right)$. In North Carolina, sampling was conducted at Coweeta Hydrologic Laboratory in the Nantahala Mountain Range in western North Carolina $\left(35^{\circ} 03^{\prime} \mathrm{N} 83^{\circ} 25^{\prime} \mathrm{W}\right)$. In Georgia, sampling was conducted at Whitehall Forest, located in the piedmont region of Clarke and Oconee Counties, Georgia $\left(33^{\circ} 53^{\prime} \mathrm{N} 83^{\circ} 21^{\prime} \mathrm{W}\right)$. In north Florida, the southernmost site, sampling was conducted at San Felasco Hammock which is in San Felasco State Park, Alachua County, Florida $\left(29^{\circ} 43^{\prime} \mathrm{N} 82^{\circ} 26 \mathrm{~W}\right)$. Permits and approval for the work was obtained from the Florida Department of Environmental Protection for permission to work on protected public land at San Felasco Hammock State Park, the US Forest Service and Coweeta LTER for permission to work on the protected public land at the Coweeta Hydrologic Laboratory, the Warnell School of Forestry for permission to work on private land at Whitehall Forest, and the Yale School of Forests for permission to work on private land at Yale Myers Forest.

Yale Myers Forest is managed for timber and is comprised primarily of even-aged northern hardwood species with understory dominated by mountain laurel (Kalmia latifolia), gently rolling topography with slopes rarely exceeding $40 \%$, elevation at or below $300 \mathrm{~m}$ above sea-level, and temperate climate (mean summer $20^{\circ} \mathrm{C}$, winter $-4^{\circ} \mathrm{C}, 110 \mathrm{~cm}$ annual rainfall [28]). Coweeta Hydrologic Laboratory is a long term site of the USDA Forest Service, Southern Research Station. Elevations range from $675-1592 \mathrm{~m}$ and annual climate is temperate (mean summer $21.6^{\circ} \mathrm{C}$, winter $1.7^{\circ} \mathrm{C}, 180 \mathrm{~cm}$ annual rainfall). Slopes are steep, ranging from $30-100 \%$. Timber was harvested until the $1920 \mathrm{~s}$ and currently the forest is largely comprised of even-aged mixed southern hardwood species with a frequently dense understory cover of Rhododendron and Kalmia species [29]. At Whitehall Forest, elevation ranges from 150-240 $\mathrm{m}$ above sea level. The forest is evenly aged (60-70 year old) southern hardwood. Climate is temperate (mean summer $25.6^{\circ} \mathrm{C}$, winter $6.7^{\circ} \mathrm{C}, 125 \mathrm{~cm}$ annual rainfall). San Felasco Hammock has a topography that is slightly rolling and elevation ranges from approximately $43-52 \mathrm{~m}$ above sea level. Climate is southern temperate (mean summer $26.9^{\circ} \mathrm{C}$, winter $12.9^{\circ} \mathrm{C}, 132 \mathrm{~cm}$ annual rainfall). The forest is secondary growth (selectively logged prior to 1937), even-aged southern hardwood forest with a high diversity of tree and understory species and a well-developed litter layer [30].

Two of the study sites were geographically close and near the center of the latitudinal range (Coweeta and Whitehall) and we recorded the highest average soil temperatures at Coweeta during sampling periods, in spite of its elevation (see Results, below). Thus, to verify that the study sites were representative of a temperate latitudinal gradient we determined the estimated annual temperatures of each site and the above ground productivity of the forest ecosystems present at each site. We used general elevation and latitude lapse rates to generate a temperature index for each site, following Warren and references therein [31]. The relative productivity (annual above ground productivity) of each site was estimated from published values in the literature [32], [33], [34], [35], [36].

\section{Sampling}

At each study site, two $10 \times 10 \mathrm{~m}$ plots were established on two north and two south facing slopes (except at YMF, where slopes face East-West), for a total of 8 plots per study site and $32100 \mathrm{~m}^{2}$ plots across all locations. Along each slope, a transect line was randomly placed and one plot was established upslope and another was established downslope, with $\sim 60 \mathrm{~m}$ separating them. Transects were separated by $100 \mathrm{~m}$ or more. Macroinvertebrates were sampled in the leaf litter, soil, and coarse woody material $(\mathrm{CWM}=$ all dead wood $>10 \mathrm{~cm}$ dia.). The sampling approach was modified to combine traditional macroinvertebrate sampling (quadrat-based rapid collection of surface material to avoid escapes) while simultaneously sampling whole colonies (ants) or feeding groups (subterranean termites) of social insects in litter, CWM, and soil. Earthworms were captured, however, this study does not properly sample earthworm abundance (c.f. [37]) so earthworm data were not analyzed separately.

To sample litter (including fine woody material, $\mathrm{FWM}=$ all dead wood $<10 \mathrm{~cm}$ dia.) and the top $\sim 5 \mathrm{~cm}$ of soil, within each $100 \mathrm{~m}^{2}$ plot, ten $25 \times 25 \mathrm{~cm}$ quadrats were established in a regularly spaced pattern (Fig. 1). In each quadrat soil temperature was measured at $5 \mathrm{~cm}$ depth and volumetric soil moisture (Campbell Hydrosense $^{\mathrm{TM}}$ ) to $12 \mathrm{~cm}$ depth. A machete was used to quickly cut (at quadrat edge) any FWM and the surface of the soil within the quadrat. The entirety of the litter sample in the quadrat down to the soil surface was then immediately collected and bagged. The remaining material from the quadrat and the top $\sim 5-10 \mathrm{~cm}$ of soil were then immediately collected using a cordless vacuum (Dewalt ${ }^{\mathrm{TM}}$ ) and bagged. If ants or termites were

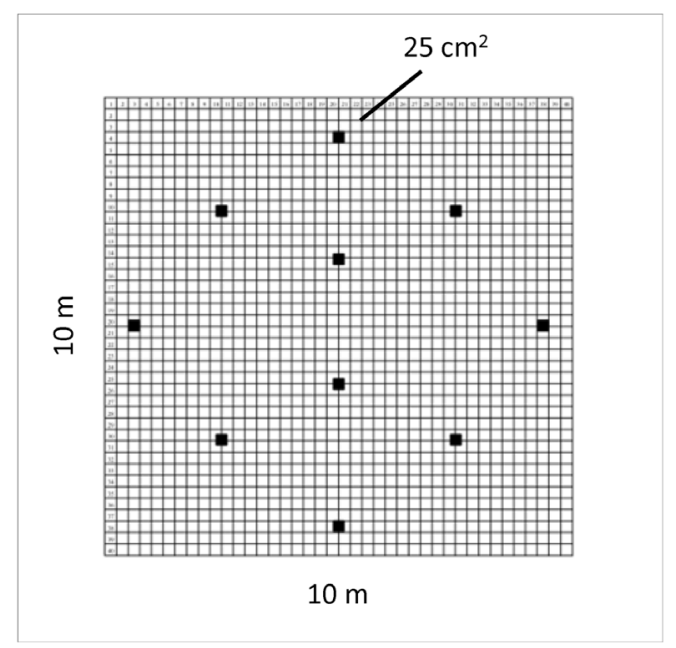

Figure 1. Arrangement of $25 \mathrm{~cm}^{2}$ quadrat samples within $100 \mathrm{~m}^{2}$ plots.

doi:10.1371/journal.pone.0075843.g001 
discovered after vacuuming, all soil to $30 \mathrm{~cm}$ depth was excavated to collect the colony. If necessary (i.e. the whole colony was not obviously collected), excavation followed the colony to the depth necessary to get the entire colony (typically no greater than $\sim 1 \mathrm{~m}$ ). Within quadrats every effort was made to collect whole colonies. The majority of ant species collected were monodomous (single nest, Table 1). Satellite nests of polydomous species (multiple nest sites per colony) outside quadrats were not collected. Any species observed were noted as collection proceeded if more than one species was present to assure collection of separate, whole colonies.

After collecting litter, within each $100 \mathrm{~m}^{2}$ plot, all CWM was measured along the center axis for length, and at either end for diameter, to estimate the volume $\left(\mathrm{cm}^{3}\right)$. Any CWM falling on the edge of plots was either cut or measured approximately (for pieces too large to cut) and sampled so as to include only CWM inside plots. For CWM small enough to bag, pieces were returned to the lab for sorting. For larger pieces, over a tarp to prevent escapes, every $50 \mathrm{~cm}$ of material was inspected and macroinvertebrates were collected.

When ant colonies or termite infestation were encountered in large pieces that could not be returned to the lab (e.g. stumps, large trees), a $15 \mathrm{~cm}$ wide piece of wood was collected, at every $50 \mathrm{~cm}$ inspection point, for sorting in the lab up to 5 encounters. Using the cordless vacuum, all of the material surrounding the collection was suctioned to assure collection of colonies. Any encounters after the first five were scored as presence and colony size was estimated visually. There were less than ten visual estimates for the entire study. Additionally, five $15 \mathrm{~cm}$ wide slices of very large CWM (without visible ants or termites) were taken and the surrounding area vacuumed and sorted in the lab.

All field material was returned to the lab and frozen on the day of collection. All material was later hand sorted after thawing. All woody material was broken apart and all litter material was carefully sorted and inspected. All macroinvertebrates were sorted to Class or Order and termites and ants were sorted to species and counted. All specimens were dried at $65^{\circ} \mathrm{C}$ prior to weighing. Voucher specimens were taken and currently reside in the University of Central Florida's insect collection.

\section{Statistical Analysis}

The primary data consisted of the abundance and dry biomass of all macroinvertebrates collected in $100 \mathrm{~m}^{2}$ plots and the number of colonies of social insects. Data were converted to $\mathrm{m}^{-2}$ and $\mathrm{m}^{-3}$ values, which represents an extrapolation of the smaller area sampled. For CWM, total abundance, number of colonies, and biomass could either be reported per unit volume $\left(\mathrm{m}^{-3}\right)$ by dividing by total volume of CWM in $100 \mathrm{~m}^{2}$ plots or per unit area $\left(\mathrm{m}^{-2}\right)$ by dividing totals per $100 \mathrm{~m}^{2}$ plot by 100 . For litter samples,

Table 1. Species of ants and termites captured at the four study sites.

\begin{tabular}{|c|c|c|}
\hline Site & Ant species & Termite species \\
\hline Yale Myers Forest & Aphaenogaster picea (Wheeler) & \\
\hline \multirow[t]{10}{*}{ Coweeta Forest } & Aphaenogaster fulva Roger & Reticulitermes flavipes(Kollar) \\
\hline & Aphaenogaster picea & \\
\hline & Camponotus chromaiodes Bolton & \\
\hline & Camponotus pennsylvanicus (De Geer)* & \\
\hline & Lasius alienus (Foerster)* ${ }^{*} \dagger$ & \\
\hline & Myrmecina americana Emery & \\
\hline & Nylanderia concinna Trager ${ }^{*} \dagger$ & \\
\hline & Nylanderia faisonensis (Forel)* ${ }^{*}$ & \\
\hline & Ponera pennsylvanica Buckley & \\
\hline & Prenolepis imparis (Say) & \\
\hline \multirow[t]{10}{*}{ Whitehall Forest } & Amblyopone pallipes (Haldeman) & Reticulitermes flavipes \\
\hline & Aphaenogaster picea & \\
\hline & Aphaenogaster rudis Enzmann & \\
\hline & Camponotus castaneus (Latreille) & \\
\hline & Nylanderia concinna* ${ }^{*} \dagger$ & \\
\hline & Nylanderia faisonensis* ${ }^{*}$ & \\
\hline & Pheidole dentata MR Smith & \\
\hline & Ponera pennsylvanica & \\
\hline & Prenolepis imparis & \\
\hline & Temnothorax curvispinosus (Mayr)** $\dagger$ & \\
\hline \multirow[t]{6}{*}{ San Felasco Forest } & Camponotus floridanus (Buckley)* & Reticulitermes flavipes \\
\hline & Formica pallidefulva Latrielle & Reticulitermes hageni Banks \\
\hline & Nylanderia faisonensis* ${ }^{*}$ & \\
\hline & Odontomachus brunneus (Patton) & \\
\hline & Pheidole dentata & \\
\hline & Pheidole dentigula MR Smith & \\
\hline
\end{tabular}

Ant species noted with an asterisk (*) are polydomous (multiple nests per colony). Ant species noted with a $\uparrow$ are polygyne (multiple queens per colony).

doi:10.1371/journal.pone.0075843.t001 
Table 2. The total abundance and dry mass of macroinvertebrates, from all plots, listed alphabetically by Class or Order.

\begin{tabular}{|c|c|c|}
\hline & Total number & Total dry mass $(\mathbf{g})$ \\
\hline \multicolumn{3}{|l|}{ Invertebrates } \\
\hline Megadrilacea (Earthworms) & 7 & 0.2941 \\
\hline Stylommatophora (Terrestrial Snails) & 539 & 5.3695 \\
\hline Isopoda (Isopods) & 33 & 0.0910 \\
\hline Chilopoda (Centipedes) & 81 & 0.5766 \\
\hline Diplopoda (Millipedes) & 216 & 7.5466 \\
\hline Araneae (Spiders) & 96 & 0.7355 \\
\hline Opiliones (Harvestmen) & 9 & 0.2778 \\
\hline \multicolumn{3}{|l|}{ Insects } \\
\hline Blattaria (Roaches) & 44 & 2.0600 \\
\hline Coleoptera (Beetles) & 324 & 3.0643 \\
\hline Diptera (Flies) & 5 & 0.0205 \\
\hline Formicidae (Ants) & 28351 & 35.477 \\
\hline Hemiptera (Bugs) & 18 & 0.2213 \\
\hline Hymenoptera (Sawflies, Wasps, Bees) & 8 & 0.0542 \\
\hline Isoptera (Termites) & 24605 & 14.464 \\
\hline Lepidoptera (Moths and Butterflies) & 74 & 1.6179 \\
\hline Orthoptera (Crickets, Katydids, Grasshoppers) & 6 & 0.3627 \\
\hline Zygentoma (Silverfish) & 1 & 0.0023 \\
\hline
\end{tabular}

Ants are listed separately, as a Family, from other Hymenoptera.

doi:10.1371/journal.pone.0075843.t002

total abundance, number of colonies, and biomass were converted to per unit area $\left(\mathrm{m}^{-2}\right)$ estimates by multiplying totals from all quadrats collected within $100 \mathrm{~m}^{2}$ plots by $1.6 \quad$ [i.e. $\left.10 \times\left(0.25 \mathrm{~m}^{2} \times 0.25 \mathrm{~m}^{2}\right) \times 1.6=1 \mathrm{~m}^{2}\right]$.

Data were analyzed in SAS version 9 using a mixed-model ANOVA design with number and dry mass of invertebrates as dependent variables and sites (Yale Myers in Connecticut, Coweeta in North Carolina, Whitehall in Georgia, and San Felasco in Florida), sociality (ants and termites versus all other invertebrates), and habitat (litter versus CWM), as classification variables and transect assigned as a random variable. Count data were $\log _{10}+1$ transformed and biomass data were $\log _{10}+0.0001$ transformed to satisfy normality and homoscedasticity assumptions. As PROC MIXED uses restricted maximum likelihood to estimate unknown covariance parameters, it was necessary to select the best-fitting covariance structure model for the data [38]. The data in all cases were best fit by the most general form possible, an unstructured covariance matrix structure, which was then used to construct the tests for fixed effects.

Approximate Type III $F$-statistics for fixed effects were calculated in PROC MIXED using a general Wald-type quadratic form [38] which we report here as $F$-statistics and associated $P$ values for localities, social and non-social invertebrates, litter and CWM and all two-way interactions. Three-way interactions were not fit because the degrees of freedom were too limited once we accounted for the spatial design of the study. We used an alpha of 0.05 to indicate significance. Inferences for fixed effects in PROC MIXED allows for comparisons across dependent variables while simultaneously accounting for the underlying covariance structure using differences of least squares means. We examined the result of multiple comparisons here as $P$-values after Tukey-Kramer adjustment.

\section{Results}

In the $3,200 \mathrm{~m}^{2}$ of forest floor that we surveyed, we found a wide diversity (16 higher taxa) and high abundance $(54,417$ individuals) of macroinvertebrates (Table 2). Ants (52\% of all macroinvertebrates sampled) and termites (45\% of all macroinvertebrates) were by far the most abundant organisms overall, becoming increasingly abundant in the southern localities [Georgia (Whitehall) and Florida (San Felasco); Table 2, Fig. 2)]. There were significant differences in the abundance of all invertebrates among sites (ANOVA, $F_{3,64}=21.1, P<0.0001$ ), between social insects and other invertebrates (ANOVA, $F_{1,64}=6.44, P=0.01$ ), and between microhabitats (CWM vs. litter; $\left.A N O V A, F_{1,64}=108, P<0.0001\right)$. There were also significant differences in the biomass of all invertebrates among sites (ANOVA, $\left.F_{3,64}=12.6, P<0.0001\right)$, between social insects and other invertebrates (ANOVA, $\left.F_{1,64}=31.0, P<0.0001\right)$, and between microhabitats $\left(A N O V A, F_{1,64}=137, P<0.0001\right)$.

There were significant two-way interactions between the main effects on abundance (ANOVA, site $\times$ habitat $F_{3,64}=14.7$, $P<0.0001$; site $\times$ sociality $F_{3,64}=10.5, P<0.0001$; habitat $\times$ sociality, $\left.F_{1,64}=46.7, P<0.0001\right)$ and dry mass $(A N O V A$, site $\times$ habitat $F_{3,64}=11.9, \quad P<0.0001$; site $\times$ sociality $F_{3,64}=9.43, \quad P<0.0001$; habitat $\times$ sociality, $F_{1,64}=68.3, P<0.0001$ ) of invertebrates (Fig. 2). These interactions demonstrate the interdependence of latitude, habitat (CWM or litter) and invertebrate type (social insects or other) on the abundance of these organisms. The social $\times$ habitat interaction was likely driven by the fact that litter samples produced a much greater abundance of macroinvertebrates than CWM samples, and that this was especially pronounced for nonsocial taxa (Fig. 2A-D). The site $\times$ habitat, and site $\times$ social, interactions presumably arose because from north to south there were large differences in macroinvertebrate abundance in litter (Fig. 2A, C) but not CWM (Fig. 2B, D). Social insects were most 

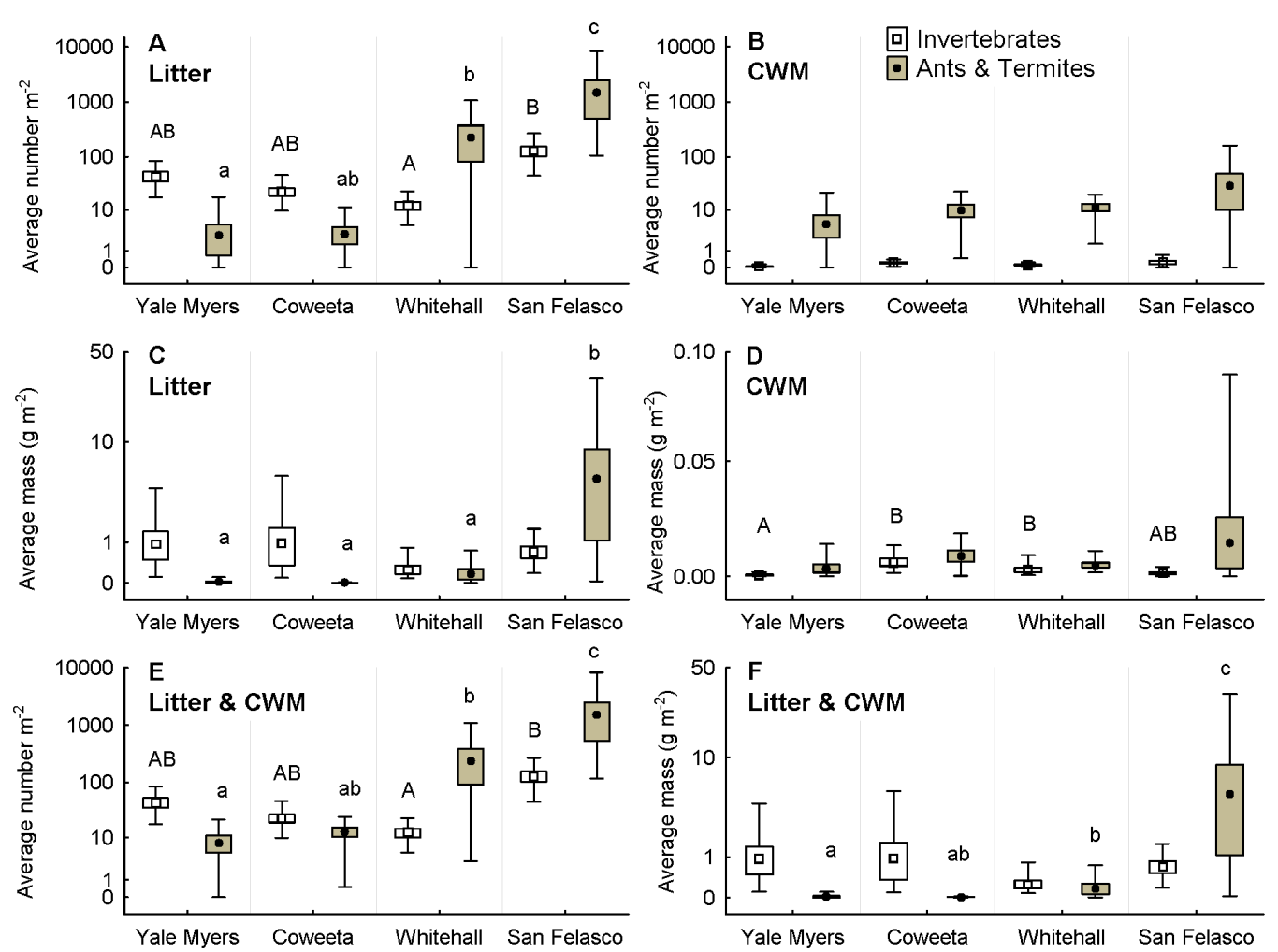

Figure 2. Macroinvertebrate biomass and abundance varied across sites, taxa, and habitats. (A) Average number of non-social invertebrates (not including ants and termites) and social insects (ants and termites) $\mathrm{m}^{-2}$ in litter samples and (B) in coarse woody material (CWM) samples. Average ants and termites $\mathrm{m}^{-2}$ differed among some sites in litter samples (A) but not in CWM (B). (C) Average dry mass of non-social invertebrates and social insects $\mathrm{m}^{-2}$ in all litter samples and (D) in CWM samples. Social insects were more abundant in San Felasco in litter samples (C) while non-social invertebrates only varied among some sites in CWM samples (D). In combined litter and CWM samples, the abundance (E) of both groups varied among sites, while only social insects varied in biomass (F). In both cases, the southern sites had higher numbers and masses of social insects $\left(E\right.$ and $F$ ). Points = mean, bars $=+/-S E$, and whiskers $=$ range. The $Y$-axis is $\log _{10}$ scaled. Letters above whiskers represent differences revealed through multiple comparisons. Shared letters of the same case (upper vs. lower) indicate no significant differences. Box plots without letters had no significant pairwise difference (Tukey-Kramer adjustment, $P>0.05$ ). doi:10.1371/journal.pone.0075843.g002

abundant at the two southern sites [Florida (San Felasco) and Georgia (Whitehall)] irrespective of habitat, but social insects were less abundant in the litter habitat at the two northern sites [North Carolina (Coweeta) and Connecticut (Yale Myers); Fig. 2A].

When litter and CWM samples were pooled, it was apparent that non-social invertebrate biomass did not differ markedly across locations, and its abundance was greatest in Florida (San Felasco) and least in Georgia (Whitehall) (Fig. 2E, F). The average dry mass of non-social invertebrates $\mathrm{m}^{-2}$ was only slightly less than $1 \mathrm{~g}$ in the two northernmost sites [0.94 g in Connecticut (Yale Myers), $0.98 \mathrm{~g}$ in North Carolina (Coweeta)], whereas it was $0.25 \mathrm{~g}$ and $0.69 \mathrm{~g}$ in Georgia and Florida, respectively (Fig 2F). In contrast, there were pronounced effects of site on social insect abundance and biomass (Fig. 2E, F), which increased as latitude decreased, resulting in the highest values for Florida, especially for ants (Fig. 3A, B). Termite abundance also increased with decreasing latitude but to less of an extent, and biomass varied only slightly across locations (Fig. 3A, B).

In Florida (San Felasco), average abundance of ants (Fig. 3A) was nearly ten times greater than that of other invertebrates (Fig. 2E) and average biomass more than ten times greater (Figs. 3B and $2 \mathrm{~F}$ ). Ant mass and abundance were, on average, a minimum of five times greater than for termites in all sites and peaked at nearly 500 times (dry mass) and 55 times (abundance) greater in Florida (Fig. 3B). In all sites except Connecticut (Yale Myers), where termites were not found (Fig. 3), there were more ant than termite species (Table 1).

Though we did not observe termites in Connecticut, Reticulitermes flavipes has long been known to be present in the state, but uncommon [39], [40], and has been observed at the Yale Myers site (MAB, pers. obs.). In litter across the other sites, the relative abundance and biomass of termites $\mathrm{m}^{-2}$ was very low (average of $<1 \%$, Fig. 3A, B) whereas ants accounted for the vast majority of social insect biomass (Fig. 3B). In contrast, except for Connecticut, termites were a major component of the abundance and biomass of macroinvertebrates in CWM (Fig. 3C, D). Thus, measuring termites $\mathrm{m}^{-3}$ CWM likely provides the most accurate estimate of standing termite biomass in eastern US temperate forests. Ant colonies also were abundant and, combined with termites, made up a large majority of the abundance of invertebrates in CWM (Yale Myers: average ant abundance $=63 \%$, average termite abundance $=0 \%$; Coweeta: ants $=71 \%$, termites $=21 \%$, Whitehall: ants $=63 \%$, termites $=36 \%$; San Felasco: ants $=30 \%$, termites $=56 \%$; Table 3 ).

The number of social insect colonies $\mathrm{m}^{-2}$ collected from litter and CWM were higher in southern sites, especially Florida (extrapolations for Yale Myers and Coweeta: $\sim 2$ colonies $\mathrm{m}^{-2}$, Whitehall: $\sim 5$ colonies $\mathrm{m}^{-2}$, San Felasco: $\sim 13$ colonies $\left.\mathrm{m}^{-2}\right)$. A' majority $(65 \%)$ of ant colonies collected included queens (were queenright) and colony size numbers (i.e. for non-queenright 


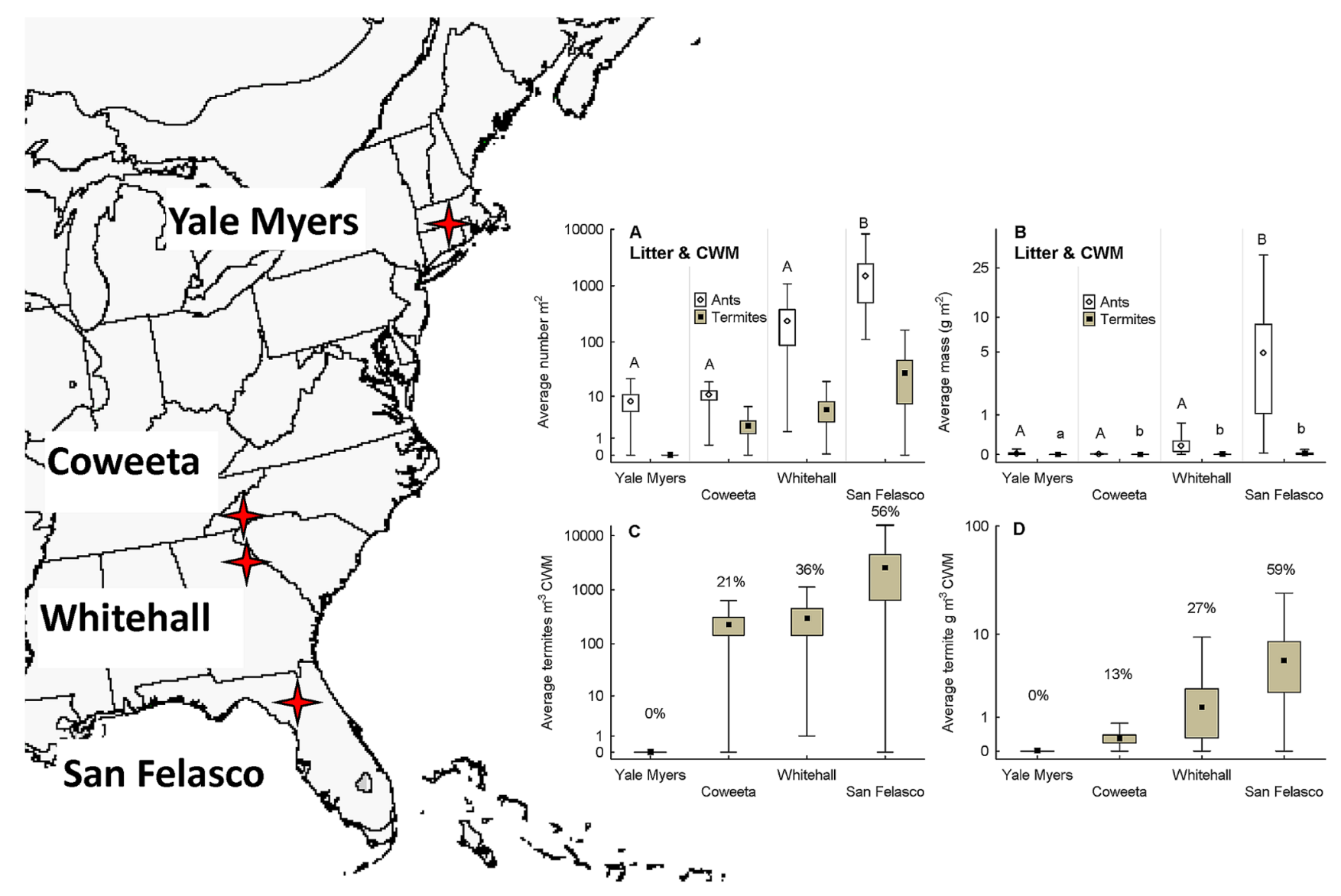

Figure 3. The location of sample sites and the average abundance $\mathrm{m}^{-2}$ (A) and $\mathbf{g}$ dry biomass $\mathrm{m}^{-2}$ (B) of ants and termites in combined litter and CWM samples. San Felasco (Florida) had a much greater abundance and biomass of ants than other sites, while termites did not vary in abundance. (C) The average $\mathrm{g}$ dry mass of termites $\mathrm{m}^{-3}$ and (D) the average number of termites $\mathrm{m}^{-3}$ in coarse woody material (CWM) in plots. Termite dry mass and numbers were zero at Yale Myers and did not differ significantly among the other sites. Points $=$ mean, bars $=+/-\mathrm{SE}$, and whiskers $=$ range. The $Y$-axis is $\log _{10}$ scaled. Percentages above whiskers in $(C$ and $D)$ represent the mean proportion of invertebrate numbers and biomass in CWM that termites comprised. Map image derived from http://upload.wikimedia.org/wikipedia/commons/d/de/Eastern_US_range_map_ blank.png, created by Alan Rockefeller.

doi:10.1371/journal.pone.0075843.g003

colony fragments) produced from this sampling method generally match other published estimates for these species [41], [42]. A few species were, by far, the most abundant both in terms of total abundance (numbers of individuals) and colony abundance, comprising greater than $50 \%$ of ant or termite workers in all sites (Table 4). Termites were almost entirely $R$. flavipes, although one colony of $R$. hageni was collected in Florida (Table 4 and Table 1).

A broad-scale pattern emerged among the most common species whereby Aphaenogaster picea was, by far, the most dominant ant in the two northernmost sites (Table 4). In Georgia (Whitehall), however, Pheidole dentata was the most common ant species (although a closely related $A$. picea congener, $A$. rudis, still was present in considerable numbers). Pheidole dentata had the most colonies in Florida, too (although the carpenter ant Camponotus floridanus had a higher number of workers and biomass in Florida due to sampling two large colonies - Table 4). The genus Aphaenogaster was not found in the Florida site although it is present in San Felasco State Park [43], whereas the species $A$. rudis and $A$. picea are not present in Florida [44]. The abundance of ants in CWM results from the predominance of Aphaenogaster and $P$. dentata colonies (Fig. 3, Table 4). These species opportunistically nest in rotting wood and will typically have portions of the nest extending into the soil (JRK, RJW, MAB pers. obs.). The highest diversity of ant species occurred in North Carolina (Coweeta) and Georgia (Whitehall), each with ten species (Table 1). These sites also had five species in common (Table 1).

Average soil temperature at the time of sampling differed among sites (ANOVA, $P<0.0001)$, as did soil moisture (ANOVA, $P<0.0001)$. Connecticut (Yale Myers) was, on average, the coolest and wettest site $\left(18.4^{\circ} \mathrm{C}, 13.2 \%\right.$ soil moisture $)$ and North Carolina (Coweeta) was the warmest and driest $\left(24.6^{\circ} \mathrm{C}, 3.2 \%\right.$ soil moisture). Georgia (Whitehall) and Florida (San Felasco) were similar $\left(22.8^{\circ} \mathrm{C}, 9.6 \%\right.$ soil moisture; $23.1^{\circ} \mathrm{C}, 5.6 \%$ soil moisture, respectively). Only termite abundance had a linear relationship with soil temperature across plots (ant abundance $P=0.25$, $R^{2}=0.04 ;$ termite abundance $P=0.02, R^{2}=0.17$; invertebrate abundance $P=0.55, R^{2}=0.01$ ) although it was weakly correlated. There was no relationship between soil moisture and abundance for any group (ant abundance $P=0.38, R^{2}=0.03$; termite abundance $P=0.21, R^{2}=0.05$; invertebrate abundance $P=0.36$, $\left.R^{2}=0.03\right)$.

Both annual temperature and productivity show that our sites are representative of a latitudinal gradient where temperature and productivity increased with decreasing latitude. Using San Felasco Hammock (the southernmost and annually warmest site) as a baseline " 0 ," assignment of general elevational and latitudinal 
Table 3. The global reported ranges of numbers of individuals $\mathrm{m}^{-2}$ and biomass $\mathrm{m}^{-2}$ for ecosystem engineers and macroinvertebrates.

\begin{tabular}{|c|c|c|c|c|c|}
\hline Source & Ants $m^{-2} / g^{-2}$ & $\begin{array}{l}\text { Termites } \\
\mathbf{m}^{-2} / \mathbf{g ~ m}^{-2 * * *}\end{array}$ & $\begin{array}{l}\text { Earthworms } \\
\mathbf{m}^{-2} / \mathrm{g} \mathrm{m}^{-2 * * *}\end{array}$ & 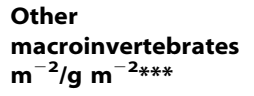 & $\begin{array}{l}\text { Ants\%/Termites \% } \\
\text { (maximum)** }\end{array}$ \\
\hline \multicolumn{6}{|l|}{ This study } \\
\hline Yale Myers $\left(41^{\circ} \mathrm{N}\right)$ & $0-22 / 0-0.102$ & $0 / 0$ & $0-3 / 0-0.300$ & $18-83 / 0.108-4.003$ & $2.5 \% / 0 \%$ \\
\hline Coweeta $\left(35^{\circ} \mathrm{N}\right)$ & $1-19 / 0.001-0.018$ & $0-6 / 0-0.005$ & $0 / 0$ & $10-47 / 0.098-5.186$ & $0.3 \% / 0.09 \%$ \\
\hline Whitehall $\left(33^{\circ} \mathrm{N}\right)$ & $2-1084 / 0.003-0.739$ & $1-19 / 0-0.013$ & $0 / 0$ & $5-23 / 0.079-0.823$ & $47 \% / 0.8 \%$ \\
\hline San Felasco $\left(29^{\circ} \mathrm{N}\right)$ & $111-8310 / 0.027-31.578$ & $0-163 / 0-0.091$ & $0 / 0$ & $45-268 / 0.185-1.506$ & $95 \% / 0.3 \%$ \\
\hline \multicolumn{6}{|l|}{ [68] Bignell \& Eggleton } \\
\hline $\begin{array}{l}\text { Tropical forests (Africa, Asia, } \\
\text { Neotropics) }\end{array}$ & NA & $38-6957 / 0-33.264$ & NA & NA & NA \\
\hline Tropical savannas (Africa) & NA & $49-4402 / 0.216-2.990$ & NA & NA & NA \\
\hline Temperate forests (Australia) & NA & NA/0.810-1.350 & NA & NA & NA \\
\hline $\begin{array}{l}\text { Temperate scrub and } \\
\text { grasslands (Australia, USA) }\end{array}$ & NA & NA/0.262-1.350 & NA & NA & NA \\
\hline \multicolumn{6}{|l|}{ [12] Wood \& Sands } \\
\hline Temperate forest (Australia) & NA & $600 / 0.810$ & NA & NA & NA \\
\hline $\begin{array}{l}\text { Semi arid savanna and } \\
\text { grasslands (North America, } \\
\text { Africa) }\end{array}$ & NA & $0-9127 / 0-5.997$ & NA & NA & NA \\
\hline $\begin{array}{l}\text { Tropical savannas (Africa, } \\
\text { Australia) }\end{array}$ & NA & $70-4402 / 0.459-2.997$ & NA & NA & NA \\
\hline $\begin{array}{l}\text { Tropical Forests (Africa, } \\
\text { Southeast Asia, Neotropics) }\end{array}$ & NA & $87-4450 / 0.027-2.970$ & NA & NA & NA \\
\hline \multicolumn{6}{|l|}{ [69] Baroni-Urbani \& Pisarski } \\
\hline $\begin{array}{l}\text { Various (mostly temperate } \\
\text { Europe and USA) }\end{array}$ & $0-115,825 / \mathrm{NA}$ & NA & NA & NA & NA \\
\hline \multicolumn{6}{|l|}{ [21] Kaspari \& Weiser } \\
\hline $\begin{array}{l}\text { Various (New World } \\
\text { temperate to tropics) }\end{array}$ & $\mathrm{NA} /<0.010-<1.000$ & NA & NA & NA & NA \\
\hline \multicolumn{6}{|l|}{ [9] Lavelle \& Spain } \\
\hline $\begin{array}{l}\text { Various (worldwide "cold," } \\
\text { temperate, and tropical) }\end{array}$ & NA & NA & $\sim 20-120 / \sim 0.6-\sim 24.3$ & NA & NA \\
\hline \multicolumn{6}{|l|}{ [14] Lavelle } \\
\hline $\begin{array}{l}\text { Tropical grasslands } \\
\text { (Ivory Coast, Mexico) }\end{array}$ & $500-1400 / 0.273-0.525$ & $2-1200 /<0.100-0.756$ & $230-700 / 3.345-7.350$ & $147-558 / 0.240-14.370$ & $0.9 \% / 1.4 \%$ \\
\hline \multicolumn{6}{|l|}{ [37] Callaham \& Hendrix } \\
\hline $\begin{array}{l}\text { Appalachian Piedmont } \\
\left(33^{\circ} \mathrm{N}, \text { USA }\right)\end{array}$ & NA & NA & $0-120 / 0-\sim 8.250 *$ & NA & NA \\
\hline \multicolumn{6}{|l|}{ [70] Shakir \& Dindal } \\
\hline $\begin{array}{l}\text { Various temperate forests } \\
\left(43^{\circ} \mathrm{N}, \text { USA }\right)\end{array}$ & NA & NA & $37-200 / 0.375-4.785^{*}$ & NA & NA \\
\hline \multicolumn{6}{|l|}{ [71] Suarez et al. } \\
\hline $\begin{array}{l}\text { Temperate hardwood forest } \\
\left(42^{\circ} \mathrm{N}, \text { USA) }\right.\end{array}$ & NA & NA & $22-99 / 0.9660-8.085$ * & NA & NA \\
\hline \multicolumn{6}{|l|}{ [72] Hendrix et al. } \\
\hline $\begin{array}{l}\text { Southeastern pine forest } \\
\left(30^{\circ} \mathrm{N}, \text { USA) }\right.\end{array}$ & NA & NA & $2 / 0.900$ & NA & NA \\
\hline \multicolumn{6}{|l|}{ [15] Petersen \& Luxton } \\
\hline Tundra & $0 / 0$ & $0 / 0$ & $\mathrm{NA} / 0.330$ & $\mathrm{NA} / 0.550$ & $0 \% / 0 \%$ \\
\hline Temperate grasslands & NA/0.1 & $0 / 0$ & NA/3.100 & $\mathrm{NA} / 1.410$ & $2 \% / 0 \%$ \\
\hline Tropical grasslands & $\mathrm{NA} / 0.3$ & NA/1.000 & NA/0.170 & NA/0.075 & $19 \% / 64 \%$ \\
\hline Temperate coniferous forests & NA/0.01 & $0 / 0$ & NA/0.450 & NA/0.570 & 1\%/0\% \\
\hline
\end{tabular}


Table 3. Cont.

\begin{tabular}{|c|c|c|c|c|c|}
\hline Source & Ants $\mathrm{m}^{-2} / \mathrm{g} \mathrm{m}^{-2}$ & $\begin{array}{l}\text { Termites } \\
\mathbf{m}^{-2} / \mathbf{g} \mathbf{m}^{-2 * * *}\end{array}$ & $\begin{array}{l}\text { Earthworms } \\
\mathbf{m}^{-2} / \mathbf{g} \mathbf{m}^{-2 * * *}\end{array}$ & $\begin{array}{l}\text { Other } \\
\text { macroinvertebrates } \\
\mathrm{m}^{-2} / \mathrm{g} \mathrm{m}^{-2 * * *}\end{array}$ & $\begin{array}{l}\text { Ants\%/Termites \% } \\
\text { (maximum)** }\end{array}$ \\
\hline Temperate deciduous forests & $\mathrm{NA} / 0.01$ & $0 / 0$ & $\mathrm{NA} / 0.200-5.300$ & $\mathrm{NA} / 1.280$ & $0.2-0.6 \% / 0 \%$ \\
\hline Tropical forests & $\mathrm{NA} / 0.03$ & NA/1.000 & $\mathrm{NA} / 0.340$ & NA/0.060 & $2 \% / 70 \%$ \\
\hline
\end{tabular}

lapse rates $\left(-6.5^{\circ} \mathrm{C}\right.$ per $1000 \mathrm{~m}$ increase in elevation and $-1{ }^{\circ} \mathrm{C}$ per $145 \mathrm{~km}$ north increase in latitude), showed that Whitehall Forest was annually $3.75^{\circ} \mathrm{C}$ cooler, Coweeta was $9.21^{\circ} \mathrm{C}$ cooler, and Yale Myers was $10.86^{\circ} \mathrm{C}$ cooler than the Florida site. Thus our sites comprise a climate gradient where temperature declined with latitude and Coweeta and Yale Myers sites (North Carolina and Connecticut) group as northern sites that were closer in annual temperature than the southern sites at Whitehall and San Felasco (Georgia and Florida). Above ground annual production by plants in each site was estimated as $1500 \mathrm{~g} \mathrm{~m}^{-2} \mathrm{yr}^{-1}$ at San Felasco Hammock, $1050 \mathrm{~g} \mathrm{~m}^{-2} \mathrm{yr}^{-1}$ at Whitehall Forest, $920 \mathrm{~g}$ $\mathrm{m}^{-2} \mathrm{yr}^{-1}$ at Coweeta, and $840 \mathrm{~g} \mathrm{~m}^{-2} \mathrm{yr}^{-1}$ at Yale Myers Forest.

\section{Discussion}

The relative abundance of ants in the southern temperate sites was unexpected and is comparable to the impressively high abundance and biomass of ants in tropical arboreal ecosystems (up to $70 \%$ of all arboreal arthropods, up to $50 \%$ of arboreal arthropod biomass; [45], [46], [47]) and higher than estimates for tropical ground-dwelling ants (e.g. [21], [48]). Furthermore, our average areal biomass estimate $\left(4.87 \mathrm{~g}\right.$ dry mass $\left.\mathrm{m}^{-2}\right)$ in Florida (San Felasco) equals or surpasses most other commonly abundant, terrestrial vertebrate, animal groups such as salamanders in northeastern temperate forest in the US $(\sim 0.05 \mathrm{~g}$ dry mass $\left.\mathrm{m}^{-2}\right)$, British Virgin Island reptile communities $(\sim 0.0001 \mathrm{~g}$ dry mass $\mathrm{m}^{-2}$ ), all large (greater than $500 \mathrm{~g}$ body weight, including elephants) mammals in equatorial rainforest in Gabon $(\sim 0.32 \mathrm{~g}$ dry mass $\left.\mathrm{m}^{-2}\right)$, mammals in dry tropical forest in Thailand $(0.73 \mathrm{~g}$ dry biomass $\mathrm{m}^{-2}$ ), mammals in a variety of neotropical forest and grassland (0.11-0.33 $\mathrm{g}$ dry biomass $\mathrm{m}^{-2}$ ) and even pastures stocked with cattle (up to $2.28 \mathrm{~g}$ dry biomass $\mathrm{m}^{-2}$ ) in Brazil (approximation of dry mass values $=0.3 \times$ fresh mass values reported in [23], [49], [50], [51], [52]).

In contrast to the patterns observed in the southern sites, termites and ants were subordinate within the macroinvertebrate communities in the northern part of the range of eastern temperate forests (Fig. 2E, F). This result supports the longstanding consensus that ants are thermophilic (warm-loving) and their abundance is greater in ecosystems with higher primary productivity, especially where temperatures are higher [1], [21], [26], [27]. Termites are also a thermophilic taxon and their abundance is greater in warmer regions [2]. Our data (Figs. 3C and D) and those of Vargo et al. [53] show a large increase in termite abundance in warmer regions within temperate zones. Temperate termite abundance may also be affected by the availability of standing and downed dead woody material (Fig. 3C, $\mathrm{D})$, however, the more northern part of the temperate zone has higher CWM stocks than in the south [54], again suggesting that cooler climate is an important limit on their abundance (Fig. 3) [53], [55], [56].

An interesting example of biogeographic turnover occurred in the most abundant ant species in CWM from northern (A. picea) to southern $(P$. dentata) sites (Table 4$)$. These two species are ecologically similar despite being in different genera. Both species opportunistically nest in decaying wood and soil, have very similar diets (both prey upon termites and both will take eliasome bearing seeds), appear to be weakly territorial or not territorial at all, and have colonies that are typically below 1,000 workers in size (JRK,

Table 4. The abundance of the most common species of ants and termites collected in each site.

\begin{tabular}{|c|c|c|c|c|c|}
\hline Social insect & Site & Species & $\begin{array}{l}\text { Number of colonies or } \\
\text { occurrences }\end{array}$ & $\begin{array}{l}\text { Average worker } \\
\text { number }\end{array}$ & $\%$ of total abundance \\
\hline Ants & Yale Myers & Aphaenogaster picea & 10 & 414 & 100 \\
\hline Termites & Yale Myers & NA & 0 & 0 & 0 \\
\hline Ants & Coweeta & A. picea & 20 & 189 & 64 \\
\hline Termites & Coweeta & Reticulitermes flavipes & 11 & 161 & 100 \\
\hline Ants & Whitehall & P. dentata & 7 & 692 & 68 \\
\hline Termites & Whitehall & R. flavipes & 13 & 181 & 100 \\
\hline Ants & San Felasco & Camponotus floridanus & 2 & 2727 & 55 \\
\hline Termites & San Felasco & R. flavipes & 12 & 1684 & 98 \\
\hline
\end{tabular}

Colony numbers (ants) and occurrences in CWM (termites) as well as average number of workers are shown. Percent of total abundance was determined for ants and termites separately as a percentage of the total number of workers captured.

doi:10.1371/journal.pone.0075843.t004 


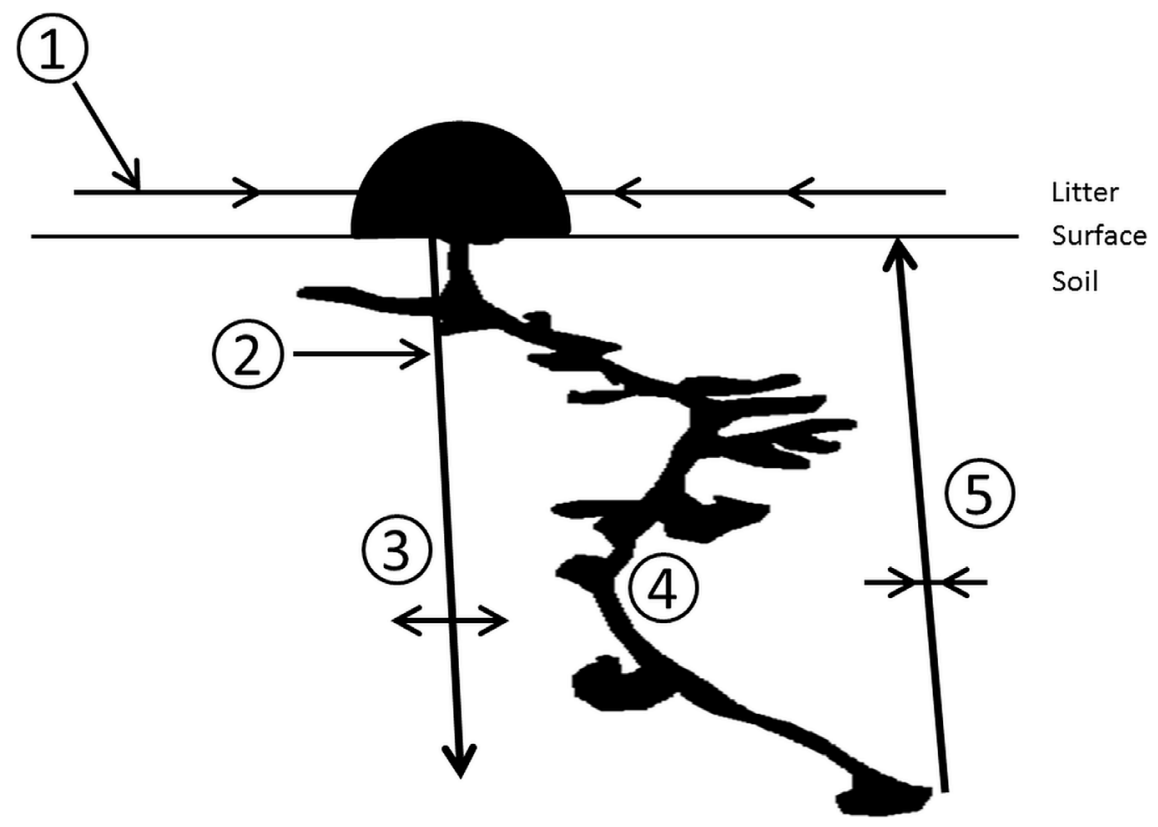

Figure 4. The myrmecosphere is centered upon ant nests constructed at the soil surface and below ground. (1) Prey and carrion, plant material, plant and insect exudates are brought into the colony. (2) Below-ground prey and carrion, plant material, plant and animal exudates are brought into the colony. (3) Materials brought into the colony are assimilated into the soil over time. (4) Feces, saliva, and other excretions are produced within the colony. (5) Soil, corpses, and midden material are returned to the soil surface.

doi:10.1371/journal.pone.0075843.g004

RJW, MAB pers. obs.). The divergence in the ant communities that occurs somewhere between North Carolina and Georgia is almost certainly under climatic influence, with the cooler temperate species (A. picea), giving way to the southeastern coastal plain species (P. dentata). Termites showed no such pattern, with $R$. flavipes remaining the dominant species throughout the entire range of the study (Table 4), but termite biomass in CWM does increase markedly between North Carolina and Georgia.

Variation in sampling protocols for soil fauna complicates the comparison of our results with other studies (i.e. Table 3). We under-sampled earthworms in our study, and possibly other groups (e.g. fast-moving large spiders), although the remaining macroinvertebrate fauna are well-represented [15]. Our sampling approach thus appears useful for estimating areal abundance of social insects and most co-occurring macroinvertebrates. Notably though, our sampling design was likely effective at estimating areal biomass but not effective at capturing whole colonies of termites. This is because termites in the genus Reticulitermes are dead woodfeeding species of the "multiple-piece nesting" functional group, which means that they feed upon decaying wood away from the primary nest where the reproductive members of the colony reside [57], [58]. Nests are cryptic and the majority of above and belowground termite abundance represents feeding rather than nesting activity (nests include sexuals and some workers), though nests sometimes are located above ground [59]. Colonies tend to be simple family groups, comprising a single reproductive pair (a queen and king) and their offspring, and maintain foraging areas typically $\leq 100 \mathrm{~m}^{2}$ in size in the southeastern US [53]. Inbreeding, larger territories, and extended family colonies become more common in the northern part of the range where abundance and colony density is also lower (Figs. 3C and D, [53]).

In contrast to termites, and due to the fact that the majority of the ant colonies collected were queenright (65\%), monogyne (single queen), monodomous (single nest) species (Table 1), our sampling protocol appears to be effective at estimating both areal biomass and colony abundance of ground-dwelling ants. Despite the high numbers and biomass we report, it is important to note that our areal abundances are still underestimates. At Yale Myers, Coweeta, and Whitehall we also searched for ants under rocks and at Yale Myers in fine woody material (FWM, $<10 \mathrm{~cm}$ dia.). Using Yale Myers as an example, in addition to the $10 \mathrm{~A}$. picea colonies in CWM we used for this analysis, we did not include seven colonies found under rocks and fourteen colonies found in FWM, which contained the only colonies with $>1,000$ workers. If this undersampling holds across all our sites, then the true biomass and numbers of ants may be $\sim 3$-times larger than the already high values we report, with the obvious caveat that these are extrapolations. We did under-sample ant species diversity because of the relatively small number of samples and use of one, rather than multiple, sampling techniques [60], [61].

Maintaining ecosystem services is a critically important, central component of global biodiversity conservation strategies [62]. Lavelle [5], [7], [9], [63] and others [2], [5], [8], [10], [16] have called attention to the central importance of social insects, along with earthworms, in maintaining soil ecosystem function and all of the associated ecosystem services. If the importance of social insects for soil processes is at least partially dependent upon biomass [12], then the data we present here suggest ants and termites are among the most important macroinvertebrates in eastern US temperate forests, at least in the southern parts of the range and likely in other temperate systems (Table 3).

Lavelle et al. [64] identify four principal systems of biological regulation of decomposition and soil structure: the litter-superficial root system, the rhizosphere, the drilosphere, and the termitosphere. The drilosphere and the termitosphere are the processes under the influence of earthworm populations and termite populations, respectively, through their activities in the soil environment. These include intestinal contents, castings, and galleries for earthworms and mounds, galleries, woody material, and gut symbionts for termites. No such system of biological 
regulation has been identified for ants: a myrmecosphere, Given the huge abundance and biomass of ants we observed in the southern part of our system, the myrmecosphere might be considered a fifth system of biological regulation in soils. It's contribution to the soil ecosystem, particularly the physical structure and chemical make-up of the soil environment [5], [10], [65], would be an emergent property of the social organization of colonies and the nests they construct and maintain [66]. The nest is the organizational centerpiece of colonial living for ants, shaping the spatial arrangement of individuals and division of labor [67] as well as the movement of materials into and out of the colony (Fig. 4). The nest is thus the "building block" of the myrmecosphere (Fig. 4). More data on areal abundance (Table 3) and the belowground activities of ants [66], [67] are necessary to better quantify the functional role of a myrmecosphere in ecosystems.

The paucity of data on ant and termite abundances is cited as the reason for omitting them from syntheses of biogeographical patterns in belowground communities [17]. Our observations begin to redress this shortcoming and reveal a pronounced shift from social insect subordinance to dominance across decreasing

\section{References}

1. Hölldobler B, Wilson EO (1990) The Ants. Harvard University Press, Cambridge, MA, USA.

2. Abe T, Bignell DE, Higashi M, eds. (2000) Termites: Evolution, Sociality, Symbioses, Ecology. Kluwer, Dordrecht, Netherlands.

3. Lach L, Parr C, Abbott K, eds. (2010) Ant Ecology. Oxford University Press, Oxford, UK.

4. Bolton B, Alpert G, Ward PS, Naskrecki P (2006) Bolton's Catalogue of the Ants of the World: 1758-2005. Harvard University Press, Cambridge, MA, USA.

5. Lobry de Bruyn LA, Conacher AJ (1990) The role of termites and ants in soil modification: a review. Australian Journal of Soil Research 28: 55-93.

6. Lavelle P, Bignell D, Lepage M, Wolters V, Roger P, et al. (1997) Soil function in a changing world: the role of invertebrate ecosystem engineers. European Journal of Soil Biology 33: 159-193.

7. Lavelle P, Decaëns T, Aubert M, Barot S, Blouin M, et al. (2006) Soil invertebrates and ecosystem services. European Journal of Soil Biology 42: S3A15.

8. Folgarait PJ (1998) Ant biodiversity and its relationship to ecosystem functioning: a review. Biodiversity and Conservation 7: 1221-1244.

9. Lavelle P, Spain AV (2001) Soil Ecology. Kluwer, Dordrecht, Netherlands.

10. Cammeraat ELH, Risch AC (2008) The impact of ants on mineral soil properties and processes at different spatial scales. Journal of Applied Entomology 132: 285-294.

11. Edwards CA, ed. (1998) Earthworm Ecology. CRC Press, Boca Raton, FL, USA.

12. Wood TG, Sands WA (1978) The role of termites in ecosystems. In: Brian, M.V. (ed.), Production Ecology of Ants and Termites. Cambridge University Press, Cambridge, UK, 245-292.

13. Brian MV, ed. (1978) Production Ecology of Ants and Termites. Cambridge University Press, Cambridge, UK.

14. Lavelle $\mathbf{P}(1984)$ The soil system in the humid tropics. Biology International 9: 2 15.

15. Petersen H, Luxton M (1982) A comparative analysis of soil fauna populations and their role in decomposition processes. Oikos 39: 287-388.

16. Lobry de Bruyn LA (1999) Ants as bioindicators of soil function in rural environments. Agriculture, Ecosystems and Environment 74: 425-441.

17. Fierer N, Strickland MS, Liptzin DL, Bradford MA, Cleveland CC (2009) Global patterns in belowground communities. Ecology Letters 12: 1238-1249.

18. Brussaard L, Aanen Dk, Briones MJI, Decaëns T, De Deyn GB, et al. (2012) Biogeography and phylogenetic community structure of soil invertebrate ecosystem engineers: global to local patterns, implications for ecosystem functioning and services, and global environmental change impacts. In: Wall, D.H. et al. (eds.), Soil Ecology and Ecosystem Services. Oxford University Press, UK, 201-232.

19. Wheeler WM (1911) The ant colony as an organism. Journal of Morphology 22: 307-325.

20. Tschinkel WR (1991) Insect sociometry: a field in search of data. Insectes Sociaux 38: 77-82.

21. Kaspari M, Weiser MD (2012) Energy, taxonomic aggregation, and the geography of ant abundance. Ecography 35: 65-72.

22. Lugo AE, Brown SL, Dodson R, Smith TS, Shugart HH (1999) The Holdridge life zones of the conterminous United States in relation to ecosystem mapping. Journal of Biogeography 26: 1025-1038. latitude in a major, temperate forest ecosystem. Termites were the most abundant macroinvertebrates in dead wood and ants were the most abundant in litter and soil. Ant abundance and biomass $\mathrm{m}^{-2}$ in the southernmost site were among the highest values recorded for ants in any ecosystem, highlighting the potential importance of these faunal groups to the belowground functioning of temperate systems.

\section{Acknowledgments}

We thank Ella Bradford, Ben Gochnour, Lindsay Gustafson, Sarah Huber, Mary Schultz and Anna Wade for field and lab assistance. We thank Edward Vargo and one anonymous reviewer for comments that greatly improved an earlier version of the manuscript. This is the Termite Ecology And Myrmecology (TEAM) working group's publication number 1.

\section{Author Contributions}

Conceived and designed the experiments: JRK RJW MAB. Performed the experiments: JRK RJW MAB. Analyzed the data: JRK RJW MAB. Contributed reagents/materials/analysis tools: JRK RJW MAB. Wrote the paper: JRK RJW MAB.

23. Burton TM, Likens GE (1975) Salamander populations and biomass in the Hubbard Brook Experimental Forest, New Hampshire. Copeia 1975: 541-546.

24. Irland LC (1999) The Northeast's Changing Forest. Harvard University Press, Petersham, MA, USA.

25. Brown WL (1973) A comparison of the Hylean and Congo-West African rain forest ant faunas. In: Meggers, B.J. et al. (eds.), Tropical Forest Ecosystems in Africa and South America: A Comparative Review. Smithsonian Institution Press, Washington, DC, USA, 161-185.

26. Andersen AN (1997) Functional groups and patterns of organization in North American ant communities: a comparison with Australia. Journal of Biogeography 24: 433-460.

27. Kaspari M, Alonso L, O'Donnell S (2000) Three energy variables predict ant abundance at a geographical scale. Proceedings of the Royal Society, B 267: 485-489.

28. Goodale E, Lalbhae P, Goodale UM, Ashton PMS (2009) The relationship between shelterwood cuts and crown thinnings and the abundance and distribution of birds in a southern New England forest. Forest Ecology and Management 258: 314-322.

29. Elliott KJ, Vose JM (2011) The contribution of the Coweeta Hydrologic Laboratory to developing an understanding of long-term (1934-2008) changes in managed and unmanaged forests. Forest Ecology and Management 261: 900910.

30. Platt WJ, Schwartz MW (1990) Temperate hardwood forests. In: Myers RL, Ewel JJ (eds.), Ecosystems of Florida. University of Central Florida Press, Orlando, FL, USA, 194-229.

31. Warren RJ (2010) A test of temperature estimation from solar irradiation and a simple statistical method to integrate elevation into prediction models. Castanea 75: $67-77$.

32. Bolstad PV, Vose JM, McNulty SG (2001) Forest productivity, leaf area and terrain in southern Appalachian deciduous forests.

33. Lugo AE, Gamble JF, Ewel KC (1978) Organic matter flows in a mixedhardwood forest in north central Florida. In: Adriano DC, Brisbin, IL (eds.) Environmental Chemistry and Cycling Processes. DOE Symposium Series, CONF-760429, 790-800.

34. Mickler RA, Earnhardt TS, Moore JA (2002) Modeling and spatially distributing forest net primary production at the regional scale. Journal of the Air \& Waste Management Association 52: 407-415.

35. Ollinger SV, Aber JD, Federer CA (1998) Estimating regional forest productivity and water yield using an ecosystem model linked to a GIS. Landscape Ecology 13: $323-334$.

36. Turner MG (1987) Land use changes and net primary production in the Georgia, USA, landscape: 1935-1982. Environmental Management 11: 237247.

37. Callaham MA, Hendrix PJF (1997) Relative abundance and seasonal activity of earthworms (Lumbricidae and Megascolecidae) as determined by hand-sorting and formalin extraction in forest soils on the southern Appalachian piedmont. Soil Biology and Biochemistry 29: 317-321.

38. Khattree R, Naik DN (1999) Applied Multivariate Statistics with SAS Software, 2nd edition. SAS Institute, Cary, NG, USA.

39. Emerson AE (1936) Termite distribution in the United States. Science 83: 410411.

40. Packard CE (1936) Termite distribution in the United States. Science 83: 575. 
41. Clark R, King JR (2012) The ant, Aphaenogaster picea, benefits from plant elaisomes when insect prey is scarce. Environmental Entomology 41: 14051408.

42. King JR (2010) Size-abundance relationships in Florida ant communities reveal how social insects break the energetic equivalence rule. Ecological Entomology 35: 287-298.

43. King JR, Porter SD (2007) Body size, colony size, abundance, and ecological impact of exotic ants in Florida's upland ecosystems. Evolutionary Ecology Research 9: 757-774.

44. Deyrup M (2003) An updated list of Florida ants (Hymenoptera: Formicidae). Florida Entomologist 86: 43-48.

45. Stork NE (1988) Insect diversity: facts, fiction, and speculation. Biological Journal of the Linnean Society 35: 321-337.

46. Tobin JE (1995) Ecology and diversity of tropical forest canopy ants. In: Lowman MD, Nadkarni NM (eds.), Forest Canopies. Academic press, NY, NY, USA, 129-147.

47. Davidson DW (1997) The role of resource imbalances in the evolutionary ecology of tropical arboreal ants. Biological Journal of the Linnean Society 61: 153-181.

48. Watt AD, Stork NE, Bolton B (2002) The diversity and abundance of ants in relation to forest disturbance and plantation establishment in southern Cameroon. Journal of Applied Ecology 39: 18-30.

49. Schaller GB (1983) Mammals and their biomass on a Brazilian ranch. Arquivos de Zoologia 31: 1-36.

50. Prins HHT, Reitsma JM (1989) Mammalian biomass in an African equatorial rain forest. Journal of Animal Ecology 58: 851-861.

51. Srikosamatara S (1993) Density and biomass of large herbivores and other mammals in a dry tropical forest, western Thailand. Journal of Tropical Ecology 9: $33-43$.

52. Rodda DH, Perry G, Rondeau RJ, Lazell J (2001) The densest terrestrial vertebrate. Journal of Tropical Ecology 17: 331-338.

53. Vargo EL, Leniaud L, Swoboda LE, Diamond SE, Weiser MD, et al. (2013) Clinal variation in colony breeding structure and level of inbreeding in the subterranean termites Reticulitermes flavipes and R. grassei. Molecular Ecology DOI: $10.1111 /$ mec. 12166 .

54. Chojnacky DC, Mickler RA, Heath LS, Woodall CW (2004) Estimates of down woody materials in eastern US forests. Environmental Management 33: S44S55.

55. Cornwell WK, Cornelissen JHC, Allison SD, Bauhus J, Eggleton P, et al. (2009) Plant traits and wood fates across the globe: rotted, burned, or consumed? Global Change Biology 15: 2431-2449.

56. Vargo EL, Husseneder C (2009) Biology of subterranean termites: insights from molecular studies of Reticulitermes and Coptotermes. Annual Review of Entomology 54: 379-403.
57. Abe T (1990) Evolution of worker caste in termites. In: Veeresh, G.K. et al. (eds.), Social Insects and the Environment. Oxford and IBH, New Delhi, India, 29-30.

58. Korb J (2007) Termites. Current Biology 17: 995-999.

59. Thorne BL, Traniello JFA, Adams ES Bulmer MS (1999) Reproductive dynamics and colony structure of subterranean termites of the genus Reticulitermes (Isoptera: Rhinotermitidae): a review of the evidence from behavioral, ecological, and genetic studies. Ethology, Ecology and Evolution 11: 149-169.

60. King JR, Porter SD (2005) Evaluation of sampling methods and species richness estimators for ants in upland ecosystems in Florida. Environmental Entomology 34: $1566-1578$.

61. Ellison AM, Record S, Arguello A, Gotelli NJ (2007) Rapid inventory of the ant assemblage in a temperate hardwood forest: species composition and assessment of sampling methods. Environmental Entomology 36: 766-775.

62. Millennium Ecosystem Assessment (2005) Ecosystems and Human Well-Being: Biodiversity Synthesis. World Resources Institute, Washington, DC, USA.

63. Lavelle P (1997) Faunal activities and soil processes: adaptive strategies that determine ecosystem function. Advances in Ecological Research 27: 93-132.

64. Lavelle P, Blanchart E, Martin A, Spain AV, Martin S (1992) The impact of soil fauna on the properties of soils in the humid tropics. In: Lal, R. and Sanchez, P.A. (eds.), Myths and Science of Soils of the Tropics, Soil Science Society of America, Madison, WI, USA, 157-185.

65. Jiménez JJ, Decaëns T, Lavelle P (2008) G and N concentrations in biogenic structures of a soil-feeding termite and a fungus-growing ant from the Colombian savannas - clues for modeling the impact of soil ecosystem engineers. Applied Soil Ecology 40: 120-128.

66. Tschinkel WR (2004) The nest architecture of the Florida harvester ant, Pogonomyrmex badius. Journal of Insect Science 4: 21.

67. Tschinkel WR (2005) The nest architecture of the ant, Camponotus socius. Journal of Insect Science 5: 9.

68. Bignell DE, Eggleton P (2000) Termites in ecosystems. In: Abe, T. et al. (eds.), Termites: Evolution, Sociality, Symbioses, Ecology. Kluwer, Dordrecht, Netherlands, 363-387.

69. Baroni-Urbani G, Pisarski B (1978) Appendix 1. In: Brian, M.V. (ed.), Production Ecology of Ants and Termites. Cambridge University Press, Cambridge, UK, 336-339.

70. Shakir SH, Dindal DL (1997) Density and biomass of earthworms in forest and herbaceous microecosystems in central New York, North America. Soil Biology and Biochemistry 29: 275-285.

71. Suarez ER, Fahey TJ, Yavitt JB, Groffman PM, Bohlen PJ (2006) Patterns of litter disappearance in a northern hardwood forest invaded by exotic earthworms. Ecological Applications 16: 154-165.

72. Hendrix PF, Callaham MA, Kirn L (1994) Ecology of Nearctic earthworms in the southern USA. II. Effects of bait harvesting on Diplocardia (Oligochaeta, Megascolecidae) populations in Apalachicola National Forest, north Florida. Megadrilogica 5: 73-76. 